\title{
THE IMAGE OF THE TURK IN EUROPE FROM 11TH TO 20TH CENTURY AS REPRESENTED IN LITERARY AND VISUAL SOURCES
}

\author{
Nedret KURAN BURÇOĞLU*
}

\begin{abstract}
The Image of the Turk emerged in Europe during the 11th Century and has evolved during the nine centuries hence forth. This article will trace this development by referring to literary and visual sources where this image is reflected. Furthermore it will focus on turning points in the paradigm of this image in the course of history and will try to reveal the socio-cultural reasons underlying these changes.
\end{abstract}

\section{Introductory Notes}

The Image of the Turk in Europe that emerged in the 11th century A.D., has gone through a dynamic process of evolution; it was formed, and has been transformed throughout the nine centuries and has been propagated al over Europe, through various types of media; through literary and visual sources that extend from chronicles, diaries and travel accounts to fairytales, from altar pieces and precious paintings to cartoons, from ballads to novels, drama and operas, from history books to newspaper articles and television programs. This image has played not an insignificant role in shaping international and intercultural relationships between the Ottoman Empire / later the Turkish Republic and other European countries. Furthermore it affected how Ottoman history has been represented in European historiography (Hann \& Fleet 1995: 157), and played a part in the creation of various European national identities. It was even influential in the formation of the "new Turk" (ibid.) during the first decade of the 20th century.

* Professor, Boğaziçi University, Director of the Centre Comparative European Studies.

[e.mail: burcoglu@boun.edu.tr] 
Given this context, I believe that it is a crucial multi-dimensional subject which has to be studied carefully from an imagological point of view, that is, from a 'supranational' and 'scientific perspective', as suggested by Hugo Dyserinck in his books and articles on Imagology, through which the mutual relationships of Turkey and other European countries in the course of history could be enlightened.

Considering the limits of space, this article will concentrate on a few examples of images that are drawn in a variety of literary sources, e.g. letters, chronicles, fairytales, poetry, drama and opera within the above mentioned time-span. To complement the corpus the article will also cover a few visual images, e.g. illustrations in books as well as paintings of European artists who belong to different Orientalist schools. The images that are mainly taken from German, Austrian, Hungarian, Bulgarian, Italian, French and British sources will be analysed in a chronological order.

\section{Phase I: The Emergence of the Image of the Turk in Europe in the 11th Century}

One of the earliest literary sources in Europe where the first seeds of the Turkish image were sown is a letter written by the Byzantine Emperor Alexius Commenus to Robert I, Earl of Flandern (1071-1093), in 1088 (Kula 1992:28). ${ }^{1}$

This is a letter of agitation where the Byzantine Emperor tries to attract the attention of the Earl of Flandern, who, being an influential leader in Europe in the 11th century, could persuade many people in Europe to participate in a holy war against the Turks. In order to justify his point the Byzantine Emperor points out in his letter that this enemy is rapidly gaining lands in Asia Minor and around the Aegean Sea and that these infidels should be considered a real threat for the Christian world as they would circumcise Christian boys in churches rape young girls at the presence of their parents, as well as commit the sin of sadomy on pious Christians (Kula 1992:). Under these circumstances the Byzantines would prefer to be under the rule of the Latins rather than be blemished by the evil deeds of this enemy of Christianity.

This skillfully structured letter has two focal points that would motivate the Christians - even the ones that lived further north, i.e quite far away from this "enemy" - for a war against the Turks:

1) protection of the wealth in Constatinopel,

2) protection of Christianity.

These motives, that shaped the negative images in the minds of Europeans, are significant as they were instrumental in creating an enemy image just before the start of the first Crusade. 
Another document from the 11th century that contains the Image of the Turk is based on a diary of an unknown soldier ${ }^{2}$ who had participated in the first Crusade. This chronicle, entitled "Historia Hierosolymitana", was written by Robertus Monachus, a priest of the Reims Cathedral who had participated in the Holy Council at Clermont in 1095, where the decision for the first Crusade was taken (Kula 1992: 34-41). Robertus Monachus was commissioned by his bishop to write this chronicle which was published in 1101 in Early High German where the Turks are designated as bloody infidels who had attacked the Christians in Jerusalem and had caused a great loss. These were merciless, brutal men who would murder the Christians without hesitation in cold blood (ibid.)

Onur Bilge Kula, in his two books entitled, The Image of the Turk in the German Culture I, II, published in 1992 and 1993 respectively, mentions several other sources that mainly consist of letters written by the Popes of the Catholic Church in the 11th and 12th centuries. The image drawn in these sources complements and enhances the negative image of the Turk in Europe that has been described in the above paragraghs. The emergence of these images coincided with the years of transition for the Turks in the Asia Minor from the rule of Principalities to the fọundation of the Ottoman Empire.

\section{Phase ll: The Evolution of the Image from the 13 th to the early 15th Century}

The following two documents- the first stemming from Mediterranean region ${ }^{3}$, and the second from Central Europe ${ }^{4}$, that date back to the 13th and 14th centuries, respectively, are significant from the point of view of the evolution of the Image in Europe as their impact lasted well into the 16th century.

The first document consists of five letters, a travel account and an essay about the confutation of the Koran written by an Italian missionary priest, called Ricoldi De Monte Croce, who was a member of the Dominican order. He made a missionary trip to the Orient and returned home in 1301. (Kula 1993: 27-66).

In his letters that he wrote upon the defeat of the Christians in Tripolis and Akkon, Monte Croce designates the Turks as the misfortune of the Christians and reproaches Jesus Christ by accusing him of passivity in front of the Muslims who had killed the Christians that were trying to protect the holy places from these infidels (ibid).

This complaint as well as the image of the Turk as the misfortune of the Christians which evolved during the 13th century was eventually concretized as the scourge or the whip of Good in German and British sources of the 16th century. This again lead to different interpretations among the clergy men, one of whom was Martin Luther, 
who having translated Monte Croce's work into German was greatly influenzed by his views - this issue will be dealt with in the following phases of the Image.

The second document of this period, that I want to mention, comprises the travel accounts of Hans Johannes Schiltberger, a Bavarian soldier, who had participated in a war under the leadership of the Hungarian King Sigmund against the Turkish Sultan Bayezit in 1394, and fell captive to the Turks among whom he had to spend 32 years of this life in Asia Minor, Caucasia, Persia and Egypt before he was allowed to return home in 1427 (Kula 1992: 72-87). In the information Schiltberger gives about the turkish war habits, Turkish traditions, way of life and religion, he tries to be as objective as possible and bases his arguments on facts. He describes war scenes where he tells in detail how much blood was shed on both sides. Furthermore Schiltberger describes the human attitude of the Turks towards their captives of war. His own situation can be considered as a proof of this attitude: Being a captive of war he was given a horse after having been kept under control for a few years and was accepted as a soldier to the army where he served for 12 years. This book that includes positive as well as negative images, was first published in Ulm, in 1476, and then republished in 1530, with an introduction added to it by Martin Luther (Kula 1992: 72).

These two documents that provided extensive information about the Turks were soon translated into many European languages and through them the images were spread all over Europe.

\section{Phase III: The Presence of both positive and negative Images side by side during the late 15th Century}

The Turks had provoked a great horror in Europeans during the Expansion Period of the Ottoman Empire that lasted until the 15th century. This horror was enhanced by the Turkish victories in Nicopolis, in 1396, in Varna, in 1444, in Kosovo, in 1448 and reached its peak in 1453 with the conquest of Istanbul by the Turkish army, under the leadership of Mehmet II. The decline of the East Roman Empire created a loss of hope in Europeans who started to see the Turks as their evil fate. The news about the defeat of the East Romans soon spread all over Europe by means of letters written by the eye-witnesses of the siege in Constantinopolis, as well as through the newly invented medium, the printing machine which was put in use in 1436. The feelings of the Europeans were soon concretized in literary and visual forms of representation.

There emerged multiple images of the Turk in Europe during the late 15th century due to various reasons. The geographic position of the countries, their distance from 
the Ottoman Empire was one of the causes of this variety. Another cause was the different consequences that were drawn from the defeat of the East Roman army by the Ottoman army. In the Balkans and the Mediterranean countries the negative image prevailed while in the northern countries a more favourable image was formed.

Nicolo Barbaro's, a Venetion noble man's diary ${ }^{5}$, which depicts the construction scenes of the Rumelihisar by the Turks during the preparation for the Conquest of Constantinople and the war scenes that followed, is an example for the former case where two motives concerning the cruel Turks were foregrounded: striking off the heads of the Christians and the Turk as the infidel (Gürol 1987: 27-31). The second image seems to be a favourite motive which is extensively used in the chivalric literature to describe the antagonist. Barbaro's book is significant as it has inspired many future Italian writers (ibid.).

In the case of Balkans, until the mid-fourteenth century, people were not so much concerned about the Turks, until then their source of information about the Islam and the Ottomans were the Orthodox church. However, the intrusion of the Turks into the Balkans have changed the situtation and the interest about this enemy among the local political and religious elites grew (Gradeva 1995: 183). Rossitsa Gradeva in her article entitled, "Turks and Bulgarians, Fourteenth to Eighteenth Century" evaluates the situation as follows:

"The conquest changed the priorities once again. It was now so important to know about Islam and about Turks. Information about their habits and way of life was abundant. The important thing became rather to find the dividing line, the contrast, to create an abominable image of the Turk/Muslim both as the followers of a different faith undermining the integrity of the Christian community, and as an alien political power, to show the reasons that brought about this disaster for Christianity and to prove the ultimate superiority of the latter. This became of vital importance for the survival of the community. It is not surprising then that Turks/Muslims were the group to which the most negative characteristics of all ethnic and religious groups in both folklore and literature were ascribed (ibid.)."

In her evaluation Gradeva has picked up some very important points which explain clearly the formation of the negative images of the Turk in the Balkans at that particular point of the history. Among them the one that with the emergence of this "Other" 'the survival of the Christian community was under threat' is repeated in other literary and visual sources which in turn served as a motivation for the creation of the 
negative images about the Turks in the Christian Europe in order to 'protect the integrity of the Christian community', (cf. Phase IV).

Co-existant with these negative images in the neighbouring countires during the second half of the 15th century there was also a positive image of the Turk that coincided with the Reformation Period of German Literature. This image was reflected in the Carnival plays (Fastnachtpiele) of the time (Kuran 1995: 239). In contrast to Mystery plays, which were mainly concerned with religious morality, Carnival plays that had developed in the German speaking lands in the medieval period, depicted scenes from everyday life. In these plays the characters turned for solutions to disputes and family feuds to secular rather than religious sources (ibid). Hans Rosenplüt's carnival plays Des Türken Fastnachtspiel and Ein Lied von dem Türken, first performed in 1454, are a case in point. In these plays the Turkish Sultan was presented to the public as the Great Turk, The Conqueror of Byzantium (Ünlü 1981: 43-44). He was depicted as a mighty, generous and just Emperor, whose subjects lived in peace and didn't have to pay tribute to the state. He had been invited by the German citizens to visit 'the free town of Nürnberg' where he would listen to their problems and suggest solutions (ibid).

The representation of the Turk in these Carnival plays hints to a fact which is mentioned in Gradiva's article above: "The TurkMuslim undermining the integrity of the Christian community". Indeed we can detect in these plays an implied criticism of the European public towards their own rulers who would force their subjects to pay tribute to them and who would treat them unjustly. This criticism is accomplished by comparing these rulers with the Turkish ruler, the Sultan, who is represented in the play as just and generous. This would have been considered a dangerous model by the rulers as well as a threat which would 'undermine the integrity of the community' and had thus to be counterbalanced with negative characteristics that can be observed in the illustrations in Hans Sachs's book at the beginning of the 16th century (figure 1).

\section{Phase IV: Increase of the negative Aspects Aspects of the Image during the 16th Century in Central Europe}

Hans Sachs (1496-1576) was a German philistine who had visualized the negative image of the Turk in his book called Die Welt des Hans Sachs. In his illustrations the Turk is shown as a cruel, merciless creature who would even kill innocent children (Kocadoru 90:175) (figure 2). Maximilian Grothaus in his book, entitled Zum Turkenbild in der Habsburger Monarchie im Ostalpenraum zwischen dem 16. und dem 18. Jahrhundert claims that with this type of illustrations that depict the rape of women and the impalement of children, an association with the biblical elements, e.g. the child murder at Bethlehem must have been envisaged (Grothaus in kocadoru 1990: 175). 
Figure 1

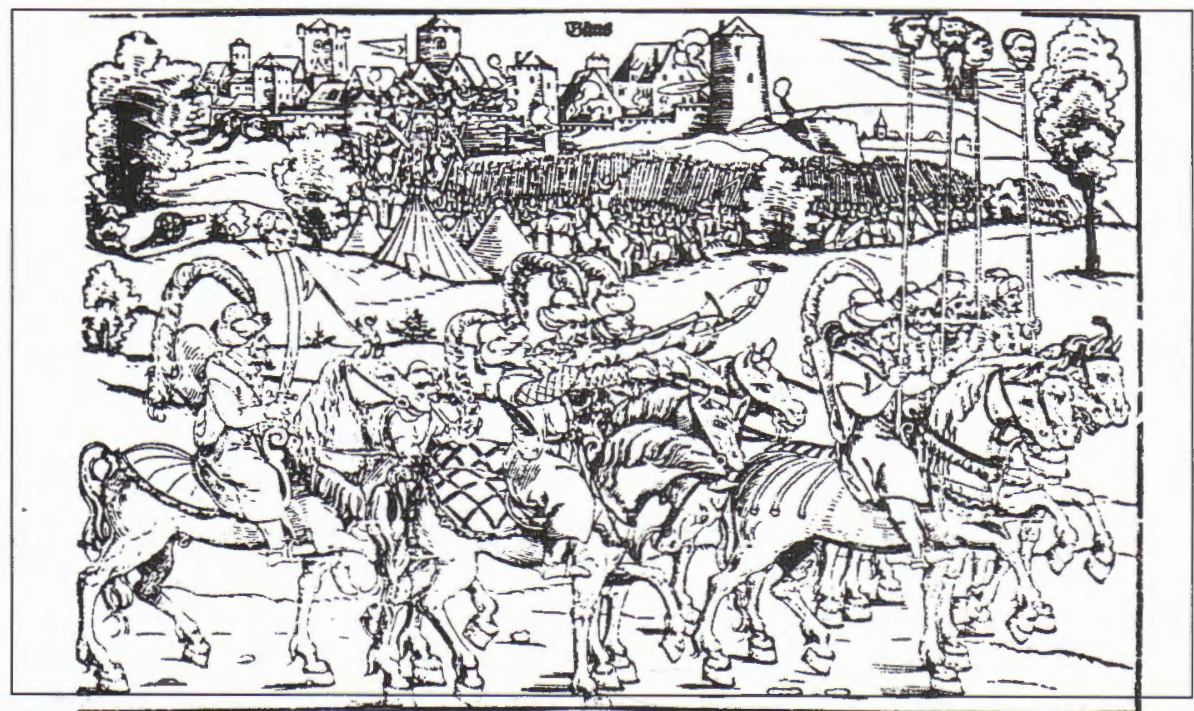

Cruel Turks parading with the Christian Skulls on their lancers after capturing their cities. Die Welt des Hans Sachs p. 146 (in Kocadoru 1990: 186)

Figure 2



Evil deeds of the Turks as represented in the book, entitled Die Welt des Hans Sachs: rape ard murder of women ard impalement of babies (in kocadoru 1990: 175) 
Since Hans Sachs was a popular author, the image he had created about the Turk was quite effective in shaping the minds of the German speaking people of Europe. This negative image was reinforced by the metaphors used in a series of impressive speeches, entitled, "Vom Kriege wider den Türken" (1529), "Heerpredigt wider den Türken" (1529), and "Vermahnung zum Gebet wider den Türken" (1541) rendered by Martin Luther (1483-1546), the religious leader of the Protestant church. In these speeches the Turks were designated as the whip or the scourge of the God, as the tool of the devil, The Turks were even equalled to the Devil and the Hell. Martin Luther put the blame of the unfavourable situation of Europe in the 16th century on both, the Catholic church and the Pope, and on the Turks. He accused the Pope of killing the souls of the Christians and the Turks the bodies of them. For him both of them should be considered the wrath of God, and unless measures were taken to protect the innocent Christians from these enemies, worse catastrophies could be expected to happen.

In Bulgarian folkloric sources, we come across a similar theme where the Catholic church, together with the Pope, are accused of misinterpreting Christianity. In addition to this, the enemy image in these sources comprise the Turks and the Greeks. On the other hand, in the Bulgarian canonized literary sources the real enemy is the Turk alone, as the Greeks and the Bulgarians were both subjects of the same eucumenical orthodox Patriarchate they are not considered as enemies eventhough they are disliked (Mutaichieva 1994: 5-40).

\section{Phase V: A Shift at the Image after 1683- the Year, that marks the second Failure of the Turks at the Siege of Vienna}

The defeat of the Ottoman army at the gate of Vienna against the European army under the leadership of Jean Sobienski caused a feeling of relief in Europeans and changed the general impression that the Turks could not be defeated. This should be taken as the second turning point, first being the Conquest of Constantinople by Mehmet II, within the history of the Image of the Turk in Europe. From that time on the Turks were associated with the concepts of ugly, cruel, treacherous, deceitful, unreliable, ridiculous and sensual. During the 17th century sarcastic feelings seem to have substituted the feelings of horror that were felt for the same people in the previous century.

Negative stereotypes can be found in the Baroque plays of German literature where Christian women are depicted as forced to choose between becoming the mistresses of Türkish rulers or face execution (Ünlü 1981:48). Catharina von Georgien, the tragedy written by A. Grypius (1616-1664) in 1651, is a case in point. 
Lohenstein's two tragedies; Ibrahim Bassa and Ibrahim Sultan (1673) have similar themes. Bulgarian literary sources also reflect similar themes of women martyrs who refuse to marry the Turks and thus sacrifice themselves. These motifs are usually accompanied with the image of the lustful Turk, who seems to threathen the social as well as the ethical values of the Christian norms of chastity and pure love. The same image is reflected in the European concepts of the Harem as well as the Türkish Bath scenes in visual sources, which seem to be popular themes also for the European painters in the 17th and 18th centuries who were representatives of different Orientalist schools.

German Comparatist Cornelia Kleinlogel, in her book called Exotik-Erotik: zur Geschichte des Türkenbileds in der deutschen Literatur der frühen Neuzeit (14531800). (Kleinlogel 1989) brings in an interesting interpretation to the Western concepts of Harem and Bath scenes in her analysis. She interprets the excessive interest towards these scenes as a "projection of repressed sensuality in Europe due to Christian prohibitive norms concerning sexuality". The French orientalist painter Jean Leon Gerome's oilpainting from the 19th century, entitled The Terrace of the Palast justifies Kleinlogel's point to the extent that it shows all naked women having a bath in open air and the Sultan watching them behind the colonades. According to the authentic sources this scene is impossible, first as an open-air bathing was not habitual in the Türkish Palasts, second as it was not a custom for the Sultan to be openly present in the bathroom of the women in Harem.

\section{Phase VI: A Shift in the negative Image due to the Concepts of "Tolerance" and "Equality of Religions" during the Enlightenment Period in the 18th Century Europe}

In contrast to the images from medieval and Baroque periods, where negative aspects were predominant, the image of the Turk in the 18th century exhibited more favourable qualities. Gotthold Ephraim Lessing (1729-1781), the playwright and critic who introduced "the philosophy of tolerance" into German culture, used a virtuous Turk to represent Islam in his famous play Nathan der Weise (1779) (Kuran 1995: 2). Inspired by the ideas propounded by the philosopher and scientist Leibniz (16461716) and his disciple Wolff (1679-1754) he expounded the idea that nobility of character has no particular relation to theological creeds. He maintained that historically, men of charitable spirit found among Jews and Muslims just as often as among Christians. For this reason he condemned adherence to any one system of dogma and taught that the development of each of the world's great religions was simply a step in the spiritual evolution of mankind. In other works of the the same 
period too, e.g. Soliman, Der Kaufmann von Smyrna, Das Grab des Mufti, Adelheit von Veltheim and Mozart's, famous opera Die Entführung aus dem Serail (1782), Turks appeared in a positive light (ibid). This depiction is an expansion of the "Turquerie" movement when Europe showed an interest in and appreciation of Turkish art and the Turkish way of life.

Following the Enlightenment well into the 19th Century an interest in the Turks in Europe persisted. This was reflected in visual as well as in literary sources. Tales that entered European literatures from the Orient in this century through translations as a new geure became soon popular. On those examples new tales were written with oriental and Turkish motifs, in which the Orient was depicted as a glamorous world of fantasies. Much space was given to descriptions of rich decorations, Oriental rugs and costumes made out of silk and other precious Oriental fabrics (figure 3 and 4) and ample use made of irrational elements and supernatural forces. The concepts of "the Turk" and "the Oriental" merged and were used interchangeably. Themes were similar to those of the previous era but these stories usually concluded with a moral message: good is rewarded and bad punished (kuran 1995: 240-241).

\section{Phase VIl: The Image after the Start of the Colonization Period in Europe}

Together with the Colonization movements in Europe during the late 18th and 19 th centuries Western perceptions concerning the Orient also changed. For colonial interests people turned their attention towards the East. Thus Oriental Studies gained impetus in Europe (Kuran 1995: 3). Extensive research was carried out and hundreds of books were written with the aim of expanding knowledge of the peoples and countries of the Orient, of their history, geography and languages, their religion, traditions, customs and way of life. Paintings depicting the Orient also became popular, thus a new school of painting in Europe, the Orientalist School evolved which flourished in countries like France, England, Austria, Italy and the Netherlands with slight differences of taste and manner. These paintings reflected a new perspective which can be summarized as follows; a desire to see and to posses the mystery and the wealth of the Orient, a nostalgia, a reflection of dreams and desires, a mysterious and enchanting Orient, precious objects, wealth, comfort, sensuality and sexual freedom for men, beautiful women, free animals, laziness, a relaxed athmosphere, lack of discipline and a slight backwardness, etc. (Kuran 1997).

It should also be pointed out however, that there was not a unique "Orientalist gaze" in Europe. There were variations. As Edward Said had pointed out in his book entitled Orientalism there were different conceptions of the Orient, e.g. the Germans who didn't have colonial interests before 1860 , had a different Orientalist discourse 


\section{Figure 3}

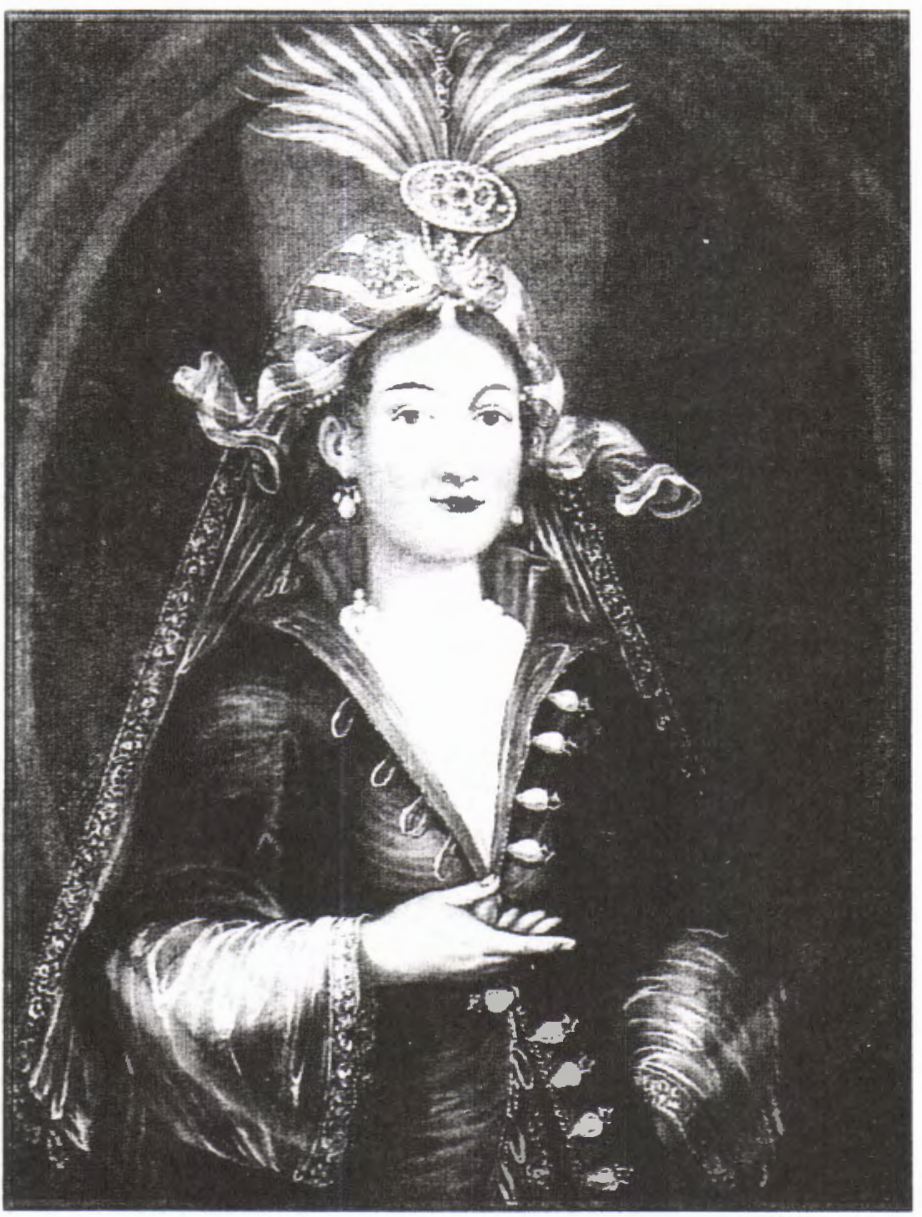

This is a reflection of the Turquerie movement on painting. The picture depicts a young Turkish woman signifying wealth, glamour and eroticism. Rich embellishments around her head reflect the exoticism, her jewelry and silk dress her wealth and her deep decoltee the eroticism that was ascribed to Orient by the Occidentals. (heritage Herberstein in Ptuj Castle Museum in Slovenia) (Ciglenecki / Grothaus 1992: 163) 
Figure 4

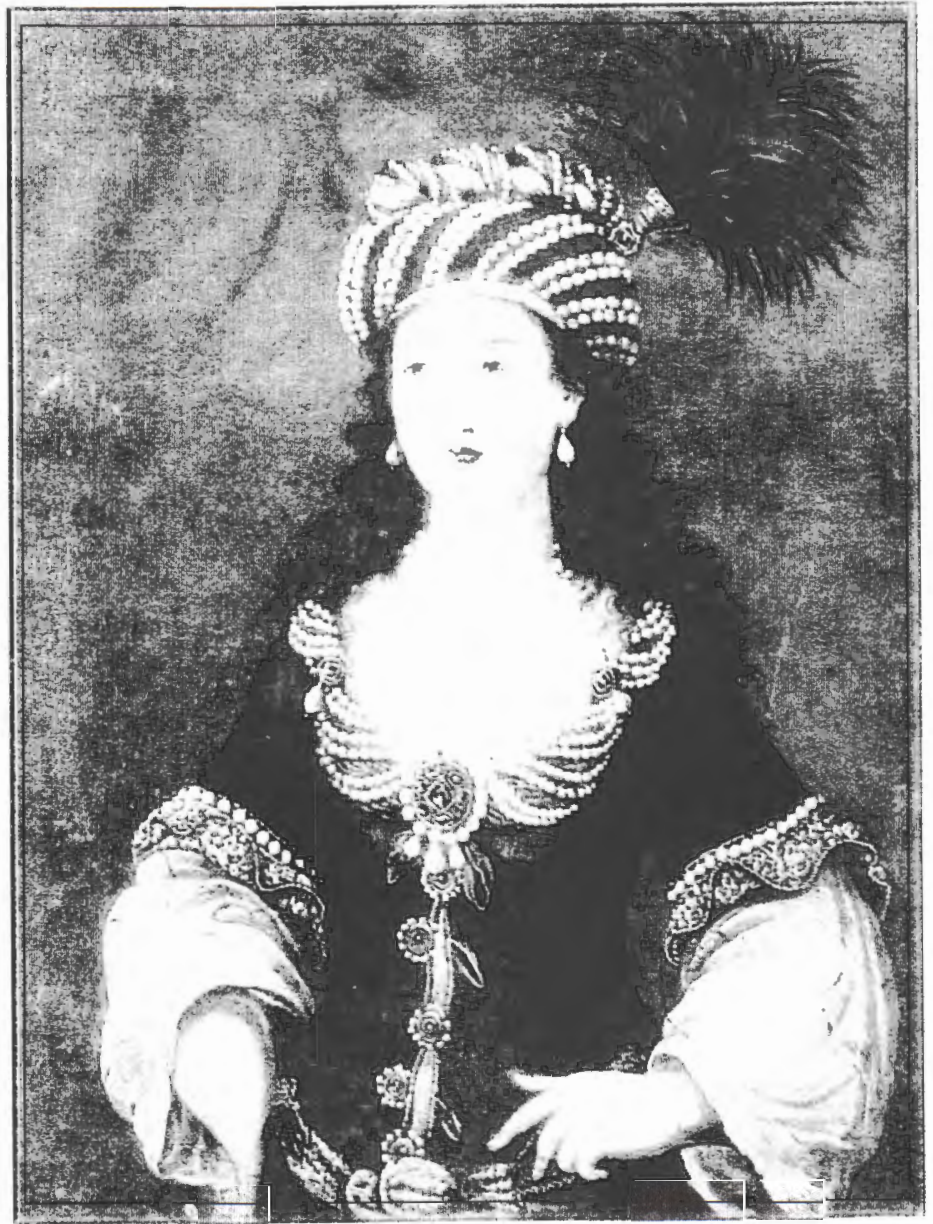

This is another example of the Turquerie movement showing an "Oriental" with a lovely head and neck decoration rich with pearls, jewelry and austrich feathers. (heritage: Herberstein in ptuj Castle Museum in Slovenia) (Ciglenecki / Grothaus 1992: 164) 
than the other people in Europe who already had colonies. So political interests could be one of the formative inputs that shaped the image, there were also other factors that affected the formation of the image. Feminist critics claim that the perspectives can vary due to differences in gender. (ibid.) Reina Lewis in her book entitled Gendering Orientalism argues that women artists are considered as "the Other" in opposition to the male artists in Europe during the 19th century. Thus the vision of these artists concerning the Orientals who were "the second other" could also be different as the one of the male artists. Thus the image formed in pictures, paintings as well as in literary sources will also be influenzed by different genders, cultures, forces and politics, which should be kept in mind in analysing the images, their formation processes and their impact on mutual human relationships.

\section{Notes}

1- The latin source identification is given in Kula (1992:28) as, Epistula Alexii Komneni imparatoris ad Robertum I comitem Flandrensem, 1088.

2- The title of the diary is given in Kula (1992:34) as, Gesta Francorum et aliorum Hierosolmitanorum, 1101.

3- The identification of this document is given in Kula (1993:27) as, Confutatio Alcorani, Picoldi De Monte Crucis, Ordinis praedicatorum, Epistulae V Commentatorial de perditione Acconis, 1291.

4- Schiltberger's Reisebuch (Travel Accounts). This influential book in handscript was copied first, then printed in Ulm, in 1476 for the first time, in Middle High German, and then published in Nürnberg, in 1530 under the title of Chronika und Beschreibung der Türckey with an Introduction written by Martin Luther (Kula 1992: 72)

5- This diary was translated into Türkish in 1976, under the title Konstantuniyye Muhasarası Ruznamesi, by Şemsettin T. Diler (Gürol 1987:28). 


\section{References}

Ciglenecki, M. \&

Grothaus, $\mathbf{M}$.

1992. Begegnung zwischen Orient und Okzident, Slovenia: Landesmuseum Ptuj.

Dyserinck, Hugo

1988. "Zur Entwicklung der komparatistischen Imagologie", Colloquium Helveticum, pp. 19-42, Bern: Peter Lang Verlag.

1981. "Komparatistische Imagologie", Komparatistik: Eine Einführung. 2. Auflage, pp. 125-133, Bonn: Bouvier Verlag.

Gürol, Ümit

Gradeva, Rossitsa

1995. "Turks and Bulgarians, Fourteenth to Eighteenth Centuries", Journal of Mediterranean Studies, edt. by Hann \& Fleet, Vol.5, Nr. 2, pp. 173-188, University of Malta: Mediterranean Institute.

Hann, lldiko \& Kate Fleet

1995. Journal of Mediterranean Studies: History, Culture and Society in the Mediterranean World (Special Issue: European Perceptions of the Ottomans), (edt.), Vol. 5, Nr. 2, University of Malta: Mediterranean Institute.

Kleinlogel, Cornelia 1989. Exotik-Erotik: zur Geschichte des Türkenbildes in der deutchen Literatur der frühen Neuzeit (1453-1800), Bochumer Schritten zur deutschen Literatur: 8 , Frankfurt am Main: Peter Lang Verlag.

Kocadoru, Yüksel 1990. Die Türken: Studien zu ihrem Bild und seiner Geschichte in Österreich, Klagenfurt.

Kula, Onur Bilge 1993. Alman Kültüründe Türk Imgesi Il, Ankara: Gündoğan Yayınları.

1992. Alman Kültüründe Türk Imgesi l, Ankara: Gündoğan Yayınları. 
Kuran-Burçoğlu, N. 1997. "The Image of the Turk from the 11th to the 20th Century in Europe", lecture given at the Historical and Archeological Institute of the Netherlands in Istanbul

1995. "The Image of the Turk in Karl May's Novel 'Vom Bagdad nach Stambul' ", Journal of Mediterranean Studies, edt. by Hann \& Fleet, Vol. 5, Nr. 2, pp. 239-247, University of Malta: Mediterranean Institute.

1994. "Karl May'da Türk Imgesi", Kuram, Kitap 6, PP.2428, yay. haz. Yurdanur Salman, Istanbul: Kur Yayıncilik.

1994. "Imagoloji Nedir?", Boğaziçi Üniversitesinden Haberler Dergisi, Sayı 2, Istanbul.

1993. "Karşılaştırmalı Yazınbilim'den Imgebilim'e", Kuram, Kitap 1, pp.77-82, yay. haz. Yurdanur Salman, Istanbul: Kur Yayıncillk.

Lewis, Reina

Mutafchieva, Vera

Ünlü, Selçuk
1996. Gendering Orientalism: Race, Femininity and Representation, London and New York: Routledge.

1994. "The Turk, The Jew and The Gypsy", Relations of Compatibility and Imcompatibility Between Christians, and Muslims in Bulgaria, pp. 5-63, Sofia: International Centre for Minority Studies and Intercultural Relations Foundation.

1981. "Alman Edebiyatında Türk Imaji" Türk Dünyası Araştırmaları, 15, Istanbul. 